\title{
Microbial mediation of benthic biogenic silica dissolution
}

\author{
Jan M. Holstein · Christian Hensen
}

Submitted: 24 August 2009 / Accepted: 27 November 2009

Published online: 22 December 2009

\begin{abstract}
Pore water profiles from 24 stations in the South Atlantic (located in the Guinea, Angola, Cape, Guyana, and Argentine basins) show good correlations of oxygen and silicon, suggesting microbially mediated dissolution of biogenic silica. We used simple analytical transport and reaction models to show the tight coupling of the reconstructed process kinetics of aerobic respiration and silicon regeneration. A generic transport and reaction model successfully reproduced the majority of Si pore water profiles from aerobic respiration rates, confirming that the dissolution of biogenic silica (BSi) occurs proportionally to $\mathrm{O}_{2}$ consumption. Possibly limited to well-oxygenated sediments poor in $\mathrm{BSi}$, benthic $\mathrm{Si}$ fluxes can be inferred from $\mathrm{O}_{2}$ uptake with satisfactory accuracy. Compared to aerobic respiration kinetics, the solubility of BSi emerged as a less influential parameter for silicon regeneration. Understanding the role of bacteria for silicon regeneration requires further investigations, some of which are outlined. The proposed aerobic respiration control of benthic silicon cycling is suitable for benthic-pelagic models. The empirical relation of BSi dissolution to aerobic respiration can be used for regionalization assessments and estimates of the silicon budget to increase the understanding of global primary and export production patterns.
\end{abstract}

Keywords Opal $\cdot$ Silicon cycle $\cdot$ Biogeochemical cycle Diatoms · Benthic Si flux · numerical modeling · CoTReM . South Atlantic

J.M. Holstein $(\bowtie)$

Institute for Chemistry and Biology of the Marine Environment

(ICBM), University of Oldenburg, P.O. Box 2503, 26111 Oldenburg,

Germany·holstein@icbm.de·文+49441 7988186

C. Hensen

Leibniz-Institut für Meereswissenschaften, IFM-GEOMAR, Wischhofstr. 1-3, 24148 Kiel, Germany · chensen@ifm-geomar.de

The final publication is available at www.springerlink.com ${ }^{2} \mathrm{AT}_{\mathrm{E}} \mathrm{X}$

\section{Introduction}

Silicon ( $\mathrm{Si}$ ) is a major nutrient in marine ecosystems. It appears mainly as ortho-silicic acid, and is essential to siliceous organisms that form skeletons composed of amorphous silica (opal). Accounting for up to half of the global oceanic primary production, diatoms by far represent the most important group of siliceous organisms (Mann, 1999; Jin et al., 2006). The dissolution of biogenic silica (BSi) starts immediately after the death of the organisms. Regionally very different, about 10 to $100 \%$ is immediately recycled within the euphotic zone, whereas the remnant is transferred to greater depths and to the seafloor (DeMaster, 1981, 2002; Nelson et al., 1995; Tréguer et al., 1995). Within the sediment, pore water profiles usually develop asymptotic (or quasi-asymptotic) Si concentrations within the upper 5 to $20 \mathrm{~cm}$ of sediment (e.g., Berelson et al., 1987; Van Cappellen and Qiu, 1997a; Rabouille et al., 1997; Zabel et al., 1998; Dixit and Van Cappellen, 2003). On average, about 3\% of the BSi produced escapes dissolution, and is removed from the global silicon cycle by burial in sediments.

Recycled Si from deceased siliceous organisms is the main silicon source for living siliceous organisms (Nelson et al., 1995; Tréguer et al., 1995). Occasionally, Si availability can become a limiting factor for diatoms (Dugdale et al., 1995; Dugdale and Wilkerson, 1998), affecting phytoplankton succession and ecosystem composition (Egge and Aksnes, 1992; Ragueneau et al., 2000). Accordingly, the interrelation of the silicon and carbon cycle, and the potential for opal to serve as a proxy for paleoproductivity emphasize the importance of gaining a better understanding of the mechanisms that govern BSi dissolution and recycling efficiency.

In this paper, we investigate the potential of microbial mediation of benthic BSi dissolution to explain observed silicon pore water profiles. We postulate a linear coupling of aer- 
obic organic matter (OM) degradation and $\mathrm{BSi}$ dissolution kinetics that is expressed (for stationary conditions) by the premises

$r(z)=\rho \cdot \stackrel{\circ}{r}(z)$

where $r$ is the BSi dissolution rate at sediment depth $z, \stackrel{\circ}{r}$ is the $\mathrm{O}_{2}$ uptake rate, a proxy for OM decay, and $\rho$ is the linear coupling coefficient. To validate the hypothesis expressed by Eq. (1), we focused on two specific objectives which were:

- to reproduce $\mathrm{Si}$ pore water profiles from $\mathrm{O}_{2}$ uptake rates using coupled reaction kinetics of aerobic OM decay and BSi dissolution. A generic diagenesis model was fitted to the $\mathrm{O}_{2}$ profiles, and the $\mathrm{Si}$ profiles were modeled according to Eq. (1), $\rho$ being the fitting parameter. Resulting $\mathrm{Si}$ effluxes are compared to fluxes derived from classical pore water profile fitting.

- to show that the kinetic rate constants of OM decay and BSi dissolution are linearly correlated. Analytical solutions of simple $\mathrm{OM}$ and $\mathrm{BSi}$ degradation models were used to reconstruct the kinetic rate constants of the reactions from the respective benthic fluxes derived with classical pore water profile fitting methods.

Based on $\mathrm{Si}$ and $\mathrm{O}_{2}$ pore water profiles at 24 continental slope locations in the South Atlantic, we used modeling and inverse modeling techniques to reveal an empirical relation of BSi dissolution to aerobic OM degradation.

\section{Background}

Several one-dimensional early diagenesis models are available to investigate the constraints of BSi recycling and preservation on a local scale in surface sediments (Luce et al., 1972; Schink et al., 1975; Kamatani et al., 1988; Boudreau, 1990a,b; Archer et al., 1993; Truesdale et al., 2005; Khalil et al., 2007). Constructed to reproduce decreasing reaction kinetics with sediment depth, these models are usually based on a first-order kinetic expressing the direct proportionality of the dissolution rate to the saturation deficit, a function of the saturation concentration and the ambient pore water $\mathrm{Si}$ concentration. Going further, Rickert et al. (2002) proposed a kinetics of higher order to account for nonlinear aspects of BSi dissolution kinetics.

Asymptotic Si concentrations are commonly assumed to represent the equilibrium solubility or saturation concentration, but they rarely if ever reach the solubility of acid-cleaned BSi (e.g., Berelson et al., 1987; Van Cappellen and Qiu, 1997a; Rabouille et al., 1997) which needs to be considered when interpreting the results of in vitro studies where acid cleaning often is the standard procedure (Barker et al., 1994; Van Cappellen and Qiu, 1997b; Greenwood et al., 2001). Additionally, asymptotic concentrations and kinetic constants both show considerable variations even on a local

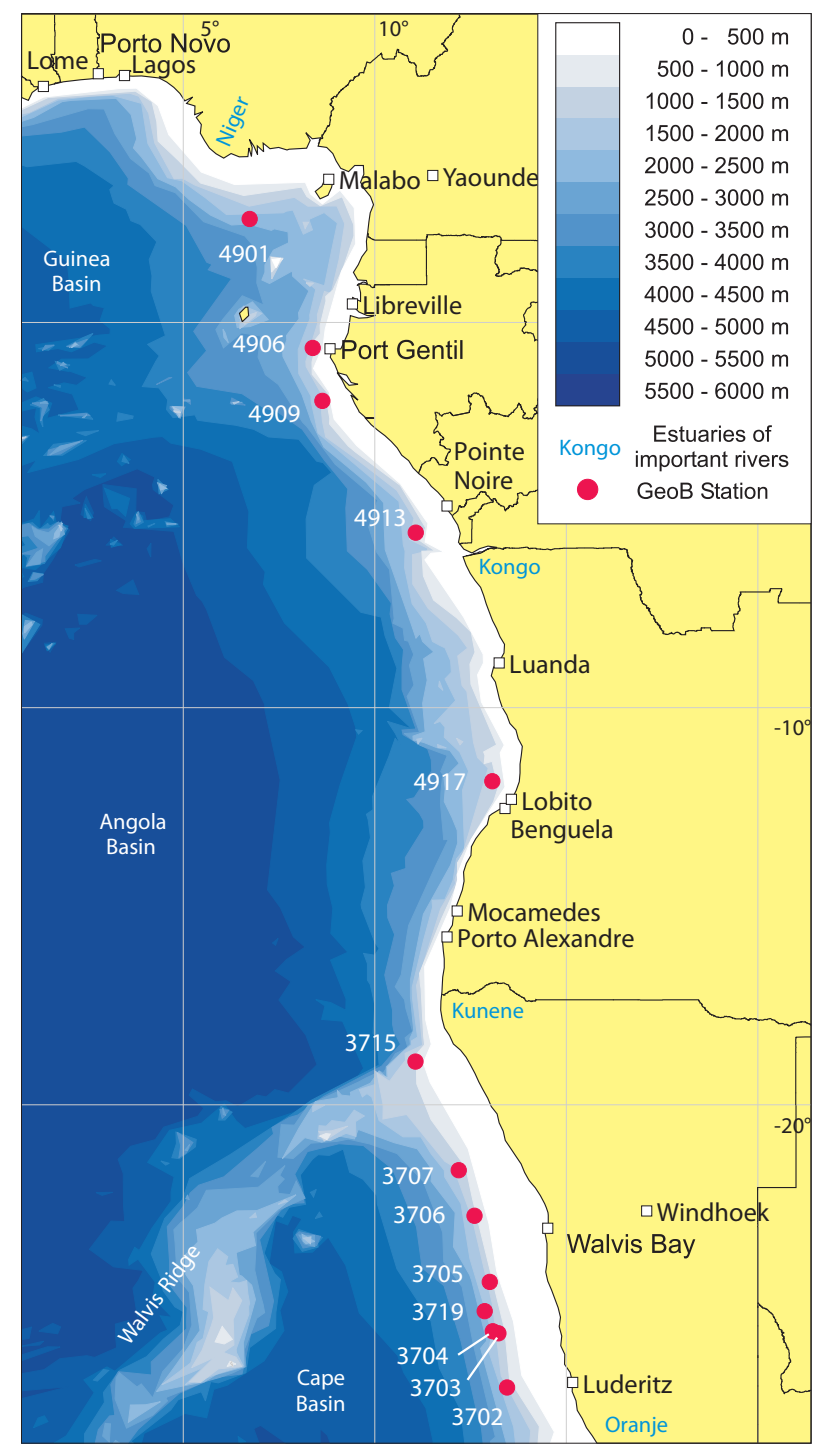

Fig. 1 Positions of investigated stations in the Guinea, Angola, and Cape basins, along the continental slope at depths between 1,200 and $2,200 \mathrm{~m}$

scale, and among sediments of similar ecosystem composition regarding silicic organisms (Schink et al., 1975; Archer et al., 1993; McManus et al., 1995; Van Cappellen and Qiu, 1997a,b).

Due to the lack of mechanistic understanding of the processes that control the local kinetic rate constant $(k)$ and the local saturation concentration $\left(C_{\infty}\right)$, early diagenetic sediment models use these as fitting parameters. Consequently, the predictive power of diagnostic silica dissolution models is limited, and models validated for a specific problem tend to fail when applied to different sites (McManus et al., 1995; Greenwood et al., 2001). From laboratory studies, the temperature, $\mathrm{pH}$, undersaturation, and electrolyte composition of the aqueous medium, as well as the specific surface area, impurity content, and aging of BSi have already been identi- 
fied as system variables of BSi solubility and dissolution kinetics (Lewin, 1961; Van Cappellen and Qiu, 1997a,b; Dixit et al., 2001; Dixit and Van Cappellen, 2002, 2003; Rickert et al., 2002). Consequently, the array of proposed mechanisms extends from diffusive transport through a boundary layer, or a solid layer leached by preferential dissolution (transport limitation), to decreasing surface area due to dissolution, formation of coatings, adsorbtion of inhibitors, or precipitation of authigenic silicates (surface chemistry limitation) (Ragueneau et al., 2000; Greenwood et al., 2001). For instance, a conclusive empirical relation in field and in vitro data exists between asymptotic Si concentration and the detrital to opal ratio in surface sediments, suggesting a significant lowering of BSi solubility by aluminum released from lithogenic mineral phases (Van Bennekom et al., 1991; Van Cappellen and Qiu, 1997a; Dixit and Van Cappellen, 2003).

However, in vitro BSi dissolution seems to be strongly accelerated by bacterial hydrolytic ectoenzymes, and to correlate with bacterial metabolic activity (Bidle and Azam, 1999, 2001; Bidle et al., 2002). Hence, BSi dissolution may relate to organic matter (OM) degradation in coastal, continental margin, and open ocean sediments, as indicated by correlations between benthic $\mathrm{Si}$ and $\mathrm{O}_{2}$ fluxes (Devol and Christensen, 1993; Hall et al., 1996), between $\mathrm{Si}$ and $\mathrm{CO}_{2}$ pore water profiles in anaerobic, non-bioturbated sediments (Berelson et al., 2005), and between $\mathrm{Si}$ and $\mathrm{NO}_{3}$ pore water profiles in well-oxygenated sediments (Martin et al., 1991).

\section{Study area, and geochemical reference data}

The study area comprises parts of the eastern Guinea, Angola, and Cape basins depicted in Fig. 1 and the Rio de la Plata sector of the western Argentine Basin depicted in Fig. 2. Pore water and sediment samples were collected during five campaigns of the RV Meteor in the Atlantic Ocean between 1994 and 1999. The 24 sampling locations are listed in Table 1, which also shows data on water depth, temperature, $\mathrm{O}_{2}$, and $\mathrm{Si}$ content of bottom waters, as well as apparent opal solubility, i.e., the asymptotic or quasi-asymptotic concentration. The stations at the South American coast are located along transects crossing the continental slope at depths between 1,492 and 5,054 m. Along the African coast, the stations are lined up between the Niger estuary in the north and the Oranje estuary in the south at depths between 1,203 and 2,177 $\mathrm{m}$. The levels of primary productivity, and hence the flux of OM, is highest in the Cape Basin, and decreases in the order Argentine Basin, Guinea Basin, and Guyana Basin (GeoB 4417; not shown). Sedimentary conditions are heavily affected by gravitational mass flow processes and the input of terrigenous material in the Argentine and Guinea basins, whereas $\mathrm{CaCO}_{3}$ precipitation prevails in the Cape Basin. For more information on the study area, the reader is

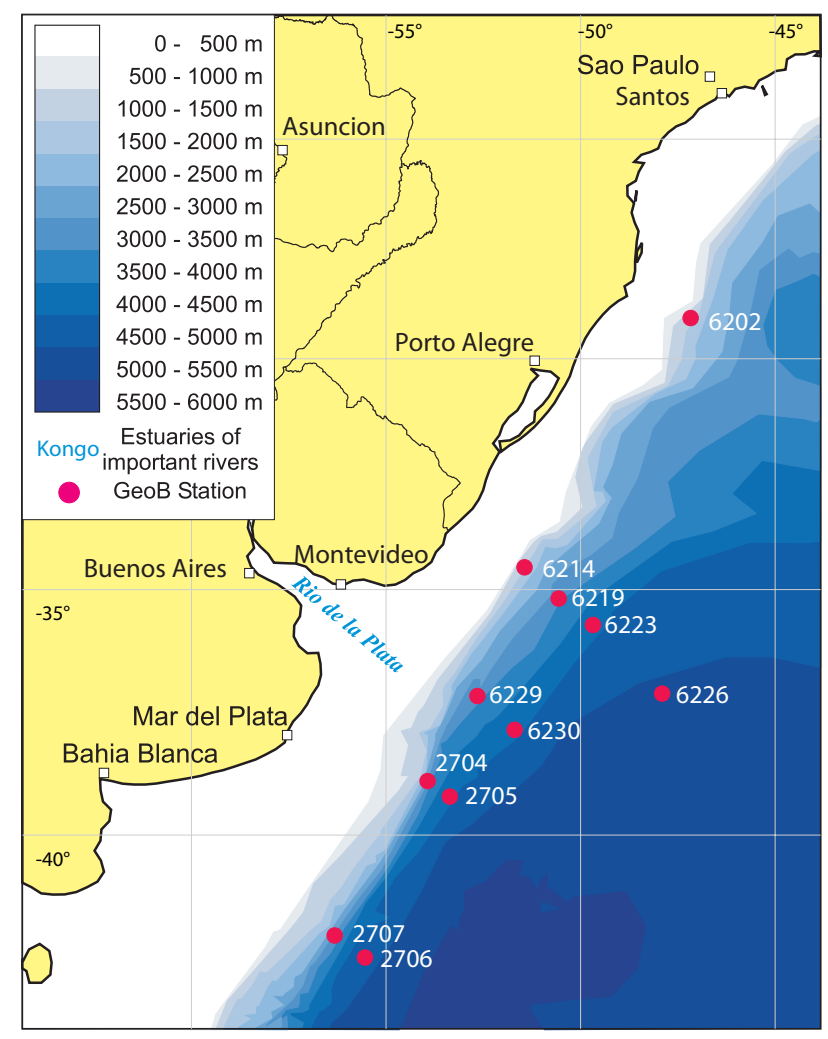

Fig. 2 Positions of investigated stations in the Argentine Basin along five transects crossing the continental slope into the abyssal plain at water depths between 1,500 and 5,000 m

referred to Hensen et al. (2000) and references therein, and Romero and Hensen (2002). The pore water and bottom water data used in this study were extracted from Hensen et al. (1998, 2000) and Wenzhöfer and Glud (2002). Opal profiles for the Guinea and Angola basins, as well as for GeoB $3706,3707,6202$, and 6214 were measured for this study using the opal extraction technique of Müller and Schneider (1993). Additional surface data for the Argentine and Cape basins were taken from Romero and Hensen (2002). $\mathrm{C}_{\text {org }}$ data were extracted from a compilation published by Seiter et al. (2004).

\section{Methods}

\section{Model description and setup}

For the modeling of BSi dissolution as a function of respiration, the generic computer model CoTReM (Landenberger et al., 1997; Adler et al., 2000) was employed. This is a onedimensional, partial differential equation-solving model describing the transport and reactions of chemical species in porous media (e.g., Berner, 1980; Boudreau, 1997). Spatial discretization is attained using finite boxes. A box volume is assigned to each node according to simple geometrical 
Table 1 Geographical position and characteristics of investigated GeoB stations arranged according to area and latitude. Temp. denotes bottom water temperature, $\stackrel{\circ}{C}_{0}$ and $C_{0}$ denote bottom water concentrations of $\mathrm{O}_{2}$ and $\mathrm{Si}$, used as boundary conditions for the simulations. $C_{\infty}$ denotes asymptotic Si concentrations. Opal and $\mathrm{C}_{\text {org }}$ are the respective fractions in bulk dry surface sediment $\left(\mathrm{Opal}: 0-0.5 \mathrm{~cm} ; \mathrm{C}_{\mathrm{org}}: 0-1.0 \mathrm{~cm}\right)$

\begin{tabular}{|c|c|c|c|c|c|c|c|c|c|}
\hline GeoB station & Longitude & Latitude & $\begin{array}{l}\text { Water depth } \\
\text { (m) }\end{array}$ & $\begin{array}{c}\text { Temp. }{ }^{\mathrm{a}} \\
\left({ }^{\circ} \mathrm{C}\right)\end{array}$ & ${\stackrel{\circ}{C_{0}}}$ & $\begin{array}{c}C_{0} \\
\left(\mu \mathrm{mol} 1^{-1}\right)\end{array}$ & $C_{\infty}$ & Opal & $\mathrm{C}_{\text {org }}$ \\
\hline \multicolumn{8}{|c|}{ Guinea \& Angola Basin } & \multicolumn{2}{|c|}{$(\%)$} \\
\hline 4901 & $06^{\circ} 43.8^{\prime} \mathrm{E}$ & $02^{\circ} 40.8^{\prime} \mathrm{N}$ & 2,177 & 3.3 & 233 & 28 & 398 & 4.7 & 0.8 \\
\hline 4906 & $08^{\circ} 22.8^{\prime} \mathrm{E}$ & $00^{\circ} 41.4^{\prime} \mathrm{S}$ & 1,272 & 4.1 & 184 & 38 & 334 & 4.4 & 2.8 \\
\hline 4909 & $08^{\circ} 37.8^{\prime} \mathrm{E}$ & $02^{\circ} 04.2^{\prime} \mathrm{S}$ & 1,305 & 4.1 & 184 & 41 & 300 & 2.7 & 2.0 \\
\hline 4913 & $11^{\circ} 04.2^{\prime} \mathrm{E}$ & $05^{\circ} 30.0^{\prime} \mathrm{S}$ & 1,300 & 3.9 & 194 & 44 & 353 & 6.0 & 1.6 \\
\hline $\begin{array}{l}4917 \\
\text { Cape Basin }\end{array}$ & $13^{\circ} 04.2^{\prime} \mathrm{E}$ & $11^{\circ} 54.6^{\prime} \mathrm{S}$ & 1,299 & 3.7 & 190 & 45 & 235 & 1.1 & 2.2 \\
\hline 3715 & $11^{\circ} 03.4^{\prime} \mathrm{E}$ & $18^{\circ} 57.3^{\prime} \mathrm{S}$ & 1,203 & 3.4 & $166^{\mathrm{b}}$ & 43 & 479 & - & 3.1 \\
\hline 3707 & $12^{\circ} 11.6^{\prime} \mathrm{E}$ & $21^{\circ} 37.4^{\prime} \mathrm{S}$ & 1,352 & 3.5 & 193 & 43 & 387 & 2.5 & 3.4 \\
\hline 3706 & $12^{\circ} 36.0^{\prime} \mathrm{E}$ & $22^{\circ} 43.0^{\prime} \mathrm{S}$ & 1,313 & 3.5 & 195 & 53 & 235 & 1.5 & 2.9 \\
\hline 3705 & $12^{\circ} 59.9^{\prime} \mathrm{E}$ & $24^{\circ} 18.1^{\prime} \mathrm{S}$ & 1,308 & 3.4 & 194 & 14 & 239 & 1.2 & 3.1 \\
\hline 3719 & $12^{\circ} 52.3^{\prime} \mathrm{E}$ & $24^{\circ} 59.7^{\prime} \mathrm{S}$ & 1,995 & 3.6 & 236 & 14 & 292 & - & 1.8 \\
\hline 3703 & $13^{\circ} 13.9^{\prime} \mathrm{E}$ & $25^{\circ} 31.1^{\prime} \mathrm{S}$ & 1,376 & 3.5 & $194^{\mathrm{b}}$ & 43 & 326 & 2.0 & 6.1 \\
\hline $\begin{array}{l}3702 \\
\text { Guyana Basin }\end{array}$ & $13^{\circ} 27.2^{\prime} \mathrm{E}$ & $26^{\circ} 47.6^{\prime} \mathrm{S}$ & 1,319 & 3.4 & $191^{\mathrm{b}}$ & 39 & 343 & 1.9 & 3.1 \\
\hline $\begin{array}{l}4417 \\
\text { Argentine Basin }\end{array}$ & $46^{\circ} 34.5 \mathrm{~W}$ & $05^{\circ} 08.2 \mathrm{~N}$ & 3,511 & 2.8 & 278 & 20 & 194 & - & 0.6 \\
\hline 6202 & $47^{\circ} 10.2^{\prime} \mathrm{W}$ & $29^{\circ} 05.2^{\prime} \mathrm{S}$ & 1,492 & 3.2 & 183 & 50 & 177 & 0.9 & 1.0 \\
\hline 6214 & $51^{\circ} 26.6^{\prime} \mathrm{W}$ & $34^{\circ} 31.6^{\prime} \mathrm{S}$ & 1,568 & 3.0 & 185 & 30 & 255 & 2.5 & 2.5 \\
\hline 6219 & $50^{\circ} 33.9^{\prime} \mathrm{W}$ & $35^{\circ} 11.1^{\prime} \mathrm{S}$ & 3,551 & 2.5 & 201 & 110 & 359 & 5.2 & 1.2 \\
\hline 6223 & $49^{\circ} 40.9^{\prime} \mathrm{W}$ & $35^{\circ} 44.4^{\prime} \mathrm{S}$ & 4,280 & 1.0 & 212 & 130 & 349 & 2.6 & 0.5 \\
\hline 6226 & $47^{\circ} 53.9^{\prime} \mathrm{W}$ & $37^{\circ} 09.5^{\prime} \mathrm{S}$ & 5,054 & 0.5 & 211 & 140 & 338 & 6.7 & 0.7 \\
\hline 6229 & $52^{\circ} 39.0^{\prime} \mathrm{W}$ & $37^{\circ} 12.4^{\prime} \mathrm{S}$ & 3,443 & 2.5 & 199 & 103 & 322 & 4.7 & 1.3 \\
\hline 6230 & $51^{\circ} 41.3^{\prime} \mathrm{W}$ & $37^{\circ} 53.7^{\prime} \mathrm{S}$ & 4,381 & 1.0 & 202 & 130 & 359 & 8.3 & 1.0 \\
\hline 2704 & $53^{\circ} 55.7^{\prime} \mathrm{W}$ & $38^{\circ} 55.5^{\prime} \mathrm{S}$ & 3,247 & 1.5 & $190^{\mathrm{b}}$ & 100 & 337 & 2.7 & 0.8 \\
\hline 2705 & $53^{\circ} 21.8^{\prime} \mathrm{W}$ & $39^{\circ} 14.6^{\prime} \mathrm{S}$ & 4,474 & 0.5 & $200^{\mathrm{b}}$ & 99 & 484 & 11.9 & 1.4 \\
\hline 2707 & $56^{\circ} 19.4^{\prime} \mathrm{W}$ & $41^{\circ} 56.7^{\prime} \mathrm{S}$ & 3,167 & 2.0 & $180^{\mathrm{b}}$ & 82 & 228 & 1.9 & 0.4 \\
\hline 2706 & $55^{\circ} 32.1^{\prime} \mathrm{W}$ & $42^{\circ} 22.1^{\prime} \mathrm{S}$ & 4,700 & 0.5 & $198^{\mathrm{b}}$ & 101 & 366 & 7.2 & 0.5 \\
\hline
\end{tabular}

${ }^{\text {a }}$ Bottom water temperatures are annual means and were taken from World Ocean Atlas Figures (WOAF98)

${ }^{\mathrm{b}} \mathrm{O}_{2}$ pore water profiles are ex situ

calculations, and the flux itself is approximated by finite differences. The model has been thoroughly tested and verified in a number of studies (Adler et al., 2001; Wenzhöfer et al., 2001; Pfeifer et al., 2002; Hensen et al., 2003). The conceptual model consists of the oxidation of OM in welloxigenated milieus according to Froelich et al. (1979)

$\mathrm{OM}+138 \mathrm{O}_{2} \rightarrow 106 \mathrm{CO}_{2}+16 \mathrm{HNO}_{3}+122 \mathrm{H}_{2} \mathrm{O}+\mathrm{H}_{3} \mathrm{PO}_{4}(2)$ with OM having a Redfield composition of 106:16:1 (C:N:P) and silica dissolution

$\mathrm{SiO}_{2}+2 \mathrm{H}_{2} \mathrm{O} \rightarrow \mathrm{H}_{4} \mathrm{SiO}_{4}$ (aq.)

Applying Eq. (1), reaction (3) is stoichiometrically coupled to reaction (2) by the target parameter $\rho$. Hence, for every mole of $\mathrm{O}_{2}$ consumed, $\rho$ moles of $\mathrm{Si}$ are released into the pore water. In order to emphasize the basic perception of microbial mediation of BSi dissolution, the model was kept as simple as possible. Factors like the availability of BSi, the $\mathrm{BSi}: \mathrm{C}_{\text {org }}$ ratio of the sediment, and $\mathrm{Si}$ saturation levels of the pore water have therefore not been considered. $\rho$ is a global parameter; it is constant over the entire sediment depth. Hence, provided conditions are stationary, Eq. (1) is valid also for the corresponding diffusive benthic fluxes

$J=-\rho \cdot \dot{J}$
The negative sign accounts for opposing directions of Si and $\mathrm{O}_{2}$ fluxes. In our model, the transport of dissolved species is expressed by diffusion only. The exchange fluxes in the model, and benthic fluxes from exponential fit were calculated according to Fick's First Law of diffusion. Diffusion coefficients for water-saturated sediment were calculated from porosity and temperature after Boudreau (1997). An exponential porosity distribution after Rabouille et al. (1997) was used with a porosity of 0.95 at the water-sediment interface, and an asymptotic porosity of 0.80 , in accordance with mean porosity data of GeoB 37 . and 62 . stations. $\mathrm{O}_{2}$ and Si concentrations in the overlying bottom water are summarized in Table 1, and were used as upper boundary conditions. The model sediment columns cover a depth range from $6-16 \mathrm{~cm}$, reaching from the water-sediment interface to a depth well below the $\mathrm{O}_{2}$ penetration depth (OPD).

\section{Pore water profile simulation and fitting}

For all stations, field $\mathrm{O}_{2}$ and $\mathrm{Si}$ pore water profiles are known. The measure for the deviation of the model or fit function from field data is the root mean squared deviation (RMSD). 
For each of the stations, $\mathrm{O}_{2}$ consumption rates were set in each model box to fit the $\mathrm{O}_{2}$ profile. Applying this method, RMSDs $<10 \mu \mathrm{mol}^{-1}$ were attained. In a second step, the coupling coefficient $\rho$ was varied in order to reproduce the Si pore water profile. The measure for fitting accuracy is a weighted RMSD. The squared errors were multiplied with the inverse distance to the sediment surface in order to favor solutions that preferably reproduce the data close to the sediment surface, and to generate accurate benthic fluxes. Using the example of GeoB 4901, Fig. 3 a shows profiles of the reaction rates of $\mathrm{O}_{2}$ consumption and opal dissolution, as well as the resulting model and field pore water concentrations. Assuming stationary conditions, $\rho$ and benthic fluxes of $\mathrm{O}_{2}$ and $\mathrm{Si}$ were determined for all 24 stations. For model val-

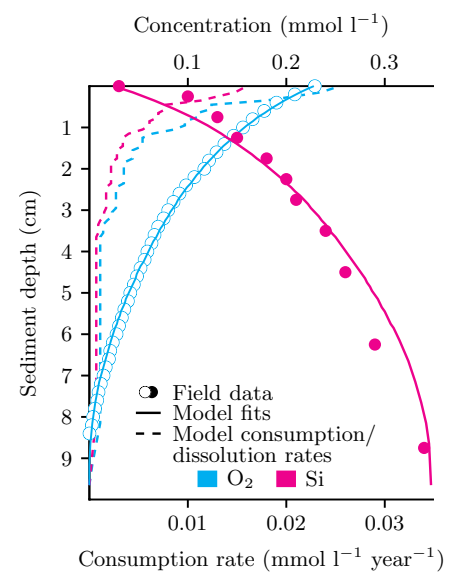

a

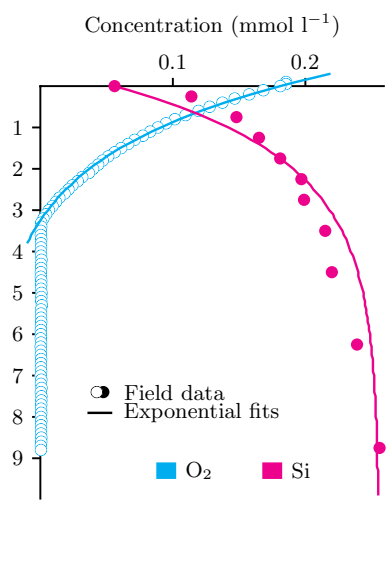

b
Fig. 3 a Example of $\mathrm{O}_{2}$ consumption rates that reproduce field concentration data for GeoB 4901. The Si consumption rates relate to those for $\mathrm{O}_{2}$ via $\rho=0.63$. b Exponential fits of GeoB 6214 pore water profiles for $\mathrm{O}_{2}$ and $\mathrm{Si}$ according to Eq. (5) and Eq. (9), respectively. Fitting parameters for $\mathrm{O}_{2}$ are $\alpha=0.53$ and $K=-0.04$. The fitting parameter for $\mathrm{Si}$ is the attenuation coefficient $\beta=0.56$

idation, benthic fluxes of $\mathrm{O}_{2}$ and $\mathrm{Si}$ were also determined by fitting exponential functions to the pore water profiles. Benthic $\mathrm{O}_{2}$ fluxes were estimated by fitting

$\stackrel{\circ}{C}(z)=\left(\stackrel{\circ}{C}_{0}-K\right) \mathrm{e}^{-\alpha z}+K$

to the pore water profiles, where $\stackrel{\circ}{C}$ is the ambient $\mathrm{O}_{2}$ concentration at sediment depth $z$, and $\stackrel{\circ}{C}_{0}$ the bottom water concentration. $K$ and $\alpha$ are fitting parameters. Fitting was done by eye. The function Eq. (5) asymptotically approaches $K$, rather than zero, which in all cases produced better fits than did e-functions asymptotically approaching zero. RMSDs varied between 1.2 and $16.0 \mu \mathrm{mol} 1^{-1}$. Benthic Si fluxes were estimated after Sayles et al. (1996) using

$C(z)=-\left(C_{\infty}-C_{0}\right) \mathrm{e}^{-\beta z}+C_{\infty}$

where $C$ is the ambient $\mathrm{Si}$ concentration, and the saturation deficit $\left(C_{\infty}-C_{0}\right)$ is the Si bottom water concentration sub- tracted from the asymptotic $\mathrm{Si}$ concentration. The attenuation coefficient $\beta$ is a free parameter determined by automatic mean squared error optimization. Using the example of GeoB 6214, Fig. 3 b shows the empirical data and the fitting functions.

Diffusive benthic fluxes in this study were derived from model fits and exponential fits to enable a meaningful comparison. Model Si fluxes a priori and systematically relate to $\mathrm{O}_{2}$ fluxes via $\rho$ whereas fluxes from exponential fit were calculated independently.

\section{Simple organic carbon and biogenic silica early diagenesis models}

Simple diffusion-reaction models of $\mathrm{Si}$ and $\mathrm{O}_{2}$ are introduced here in order to separate the effects of kinetics, boundary conditions, and material properties. Based on theese models, rate coefficients of aerobic OM degradation and BSi dissolution reactions were calculated from benthic fluxes.

According to the one-dimensional, steady-state and constant porosity approach, pore water solute concentrations are described by the mass continuity equation

$D \frac{\partial^{2} C}{\partial z^{2}}+R=0$

where $D$ is the diffusivity of the solute, $C$ the ambient solute concentration per unit volume pore water at sediment depth $z$, and $R$ describes the generation (or removal) rate of $C$ per unit volume pore water. In the case of BSi diagenesis, a simple implementation of $R$ in Eq. (7) would be

$R=r=k\left(C_{\infty}-C\right)$

where $k$ is the first-order kinetic rate constant, and $C_{\infty}$ the asymptotic Si concentration and the assumed solubility of BSi. Intentionally, any dependence on the reactive surface area-e.g.,the BSi content (Schink et al., 1975), or particle concentration (Keir, 1982)-is omitted. Since we do not investigate the recycling efficiency, the omission is not critical as long as the model application is limited to sites where opal content does not greatly decrease with sediment depth (for example, because of sufficient mixing in the zone of principal opal dissolution). This seems to be the case in the present study area, according to existing opal depth profiles (data not shown). From the analytical solution

$C(z)=C_{\infty}-\left(C_{\infty}-C_{0}\right) \mathrm{e}^{-b z}$ with $\quad b=\sqrt{k / D}$

which is known to fit most Si pore water profiles well (cf. Eq. 6), benthic fluxes were calculated as

$\left.J(z)\right|_{z=0}=\phi D \frac{\partial C}{\partial z}=\phi D b\left(C_{\infty}-C_{0}\right)$

where $\phi$ is the porosity.

In the case of $\mathrm{O}_{2}$ transport and consumption, an appropriate implementation of $R$ in Eq. (7) is

$\stackrel{\circ}{R}=\stackrel{\circ}{r}=-\stackrel{\circ}{k} \stackrel{\circ}{ }$ 
where $\stackrel{k}{k}$ is the first-order rate constant. In analogy with considerations made for Eq. (8), any surface area dependence is omitted. Instead, the kinetic rate constant $k$ is quality scaled, accounting for OM fractions differing in degradability. High values indicate labile OM, low values refractory OM. Again, from the analytical solution

$\stackrel{\circ}{C}(z)=\stackrel{\circ}{C_{0}} \mathrm{e}^{-\stackrel{\circ}{b} z}$ with $\stackrel{\circ}{b}=\sqrt{\stackrel{\circ}{k} / \stackrel{\circ}{D}}$

the benthic fluxes were calculated as

$\left.\stackrel{\circ}{J}(z)\right|_{z=0}=-\phi \stackrel{\partial}{\partial} \frac{\partial}{\partial z}=\phi \stackrel{D}{2} \stackrel{\circ}{C_{0}}$

We use these simple analytical models to convert the premises given in Eq. (1) into a hypothesis that is amenable to validation. From Eqs. (1) (with Eqs. 8 and 11) and (4) (with Eqs. 10 and 13), we derive that hypothesis of coupled reaction kinetics of BSi dissolution and aerobic respiration:

$\mathrm{H}_{1}: \quad k_{\mathrm{i}}=\frac{D}{\stackrel{\circ}{D}} \stackrel{\circ}{\mathrm{i}}_{\mathrm{i}}$

were $i=1, \ldots, 24$ is the station index. The kinetic rate constants are calculated from benthic fluxes according to Eqs. (10) and (13).

The significance level for hypothesis testing is $1 \%$.The employed measure for linear correlation is the Pearson product moment correlation coefficient $r$.

\section{Results}

Near-perfect model fits for $\mathrm{O}_{2}$ profiles were obtained by calibrating aerobic respiration rates. From aerobic respiration rates, the $\mathrm{Si}$ pore water profiles could generally be reproduced very well (with RMSDs of 10-106, on av. $31 \mu \mathrm{mol} 1^{-1}$ ) using the coupling coefficient $\rho$ as a fitting parameter with values between 0.3 and 0.9 , as depicted in Fig. 4. The mean coupling coefficient $\bar{\rho}=0.52$ has a standard deviation of $\sigma=0.14$. Asymptotic Si concentrations are reached mostly at or in close proximity of the OPD. Ranging from $0.8-14 \mathrm{~cm}$, OPDs increase basinward, reflecting the decrease in $\mathrm{C}_{\text {org }}$ content with water depth. Exponential fits of $\mathrm{O}_{2}$ were nearly perfect (with RMSDs of 1.3-16.0, on av. $4.8 \mu \mathrm{mol}^{-1}$ ). The exponential fits of Si profiles are mostly good (with RMSDs of $19-104$, on av. $46 \mu \mathrm{moll}^{-1}$ ), but less accurate than the model fits. Fluxes from model and exponential fits are listed in Table 2. $\mathrm{O}_{2}$ fluxes from model and exponential fit are very similar. By contrast, Si fluxes determined by the two methods show some divergence, up to $40 \%$ at a given location, and $20 \%$ on average. For a better overview, ease of description and later interpretation, the sets of $\mathrm{O}_{2}$ and $\mathrm{Si}$ pore water profiles were assigned to one of three categories, i.e., type I to type III, based mainly on the shape of the Si pore water profiles relative to the OPDs:
- Type I pore water profiles have smooth Si profiles approaching an asymptotic or quasi-asymptotic concentration at about the OPD. Compared to profiles of the other types, they have relatively high OPDs (av. $4.3 \mathrm{~cm}$ ), and low surficial $\mathrm{C}_{\text {org }}$ contents (av. 1.4\%). Evidently, there is a good overall fit of the model to the data. The only systematic exception are the uppermost Si concentration values within the sediment. These outliers can also be seen in the pore water profiles of other parameters (NO3, PO4), and may be ascribed to recovery artifacts (e.g., Glud et al., 1994; Hensen et al., 1998). Altogether, 14 stations belong to this category (Fig. $4 \mathrm{a}-\mathrm{n}$ ).

- Type II pore water profiles resemble type I within the oxic zone, but do not develop to an asymptotic Si concentration. Instead, they show a Si concentration maximum at about the OPD. Below, Si concentrations decrease, with a 3-4 cm thick plateau preceding the decline. Down to the OPD, which is low $(<1 \mathrm{~cm})$, the simulated Si pore water profiles fit the data very well. The $\mathrm{C}_{\text {org }}$ content is high ( $4.6 \%$ ). Only two stations show this behavior (Fig. 4o, p).

- Type III pore water profiles differ from type I profiles in reaching their asymptotic Si concentrations below the OPD, or not reaching asymptotic Si concentrations at all, i.e., Si concentrations seem to keep increasing with depth. However, the major increase in pore water Si occurs within the OPD, restricting the relevant dissolution processes to the oxic layer. Like type II, they show low OPDs (av. $1.0 \mathrm{~cm}$ ), but the surficial $\mathrm{C}_{\text {org }}$ content ( av. 1.7\%) is intermediate. Eight stations belong to this category (Fig. 4q-x).

The profile types seem to be clustered on a regional scale. Most Guyana and Angola basin stations are type III, and in the Argentine and Cape basins the type III and type II sites are in close proximity.

At type I and type II stations, which make up two-thirds of the investigated stations, BSi dissolution rates can be inferred from aerobic respiration rates, and $\mathrm{Si}$ pore water profiles are reproduced with high accuracy. In the case of the remaining profiles (type III), the simulations fail to reproduce the asymptotic Si concentrations. Still, the zone of principal BSi dissolution coincides with the oxic zone, and in many cases simulations fit type III Si profiles well within the oxic zone.

There is excellent matching of the kinetic rate constants $k$ and $k$ of BSi dissolution and aerobic respiration for type I and type II profiles shown in Fig. 5 a, suggesting a coupled kinetics of both reactions. Statistical analysis reveals that the variance of kinetic rate constants of aerobic respiration account for $85 \%$ of the Si flux variability, but only $5 \%$ of the Si flux variability is accounted for by solubility variance $(17 \%$ is accounted for by the variability of the saturation deficit, $\left.C_{\infty}-C_{0}\right)$. The BSi dissolution kinetic rate constant $k$ spans 


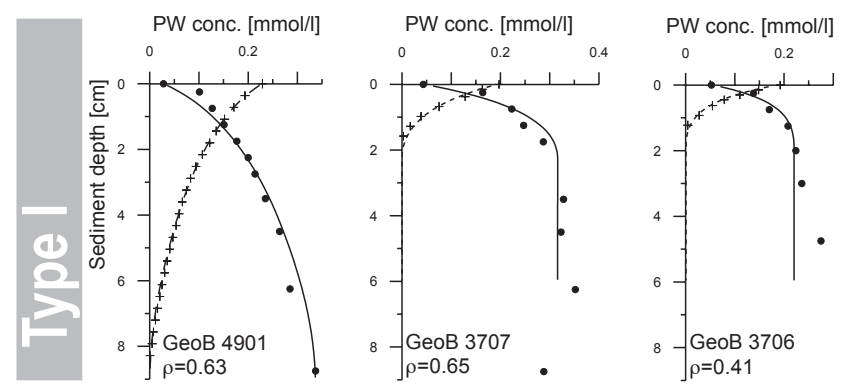

a

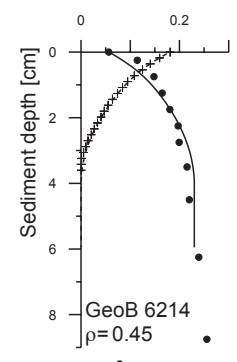

h

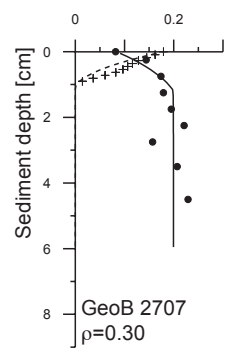

n

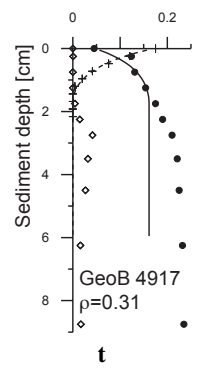

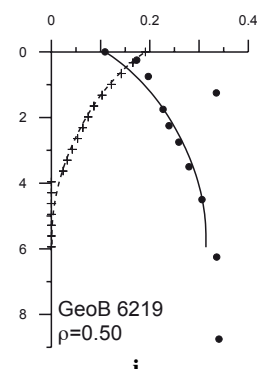
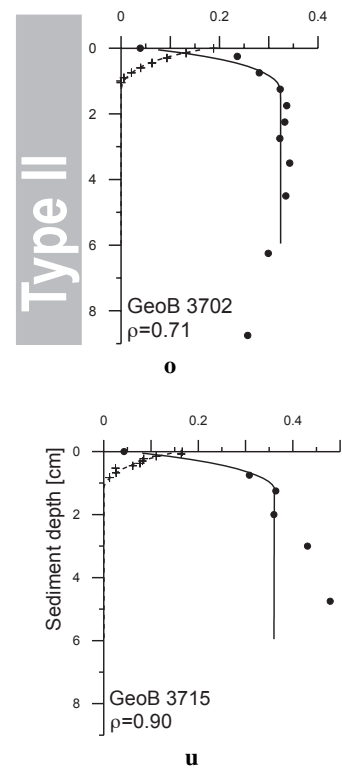

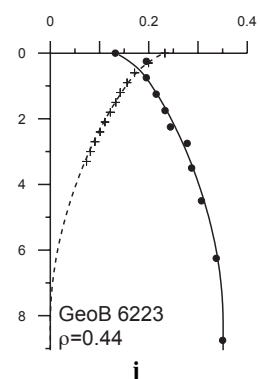

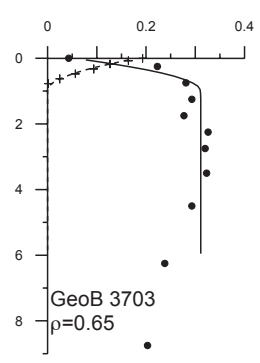

p

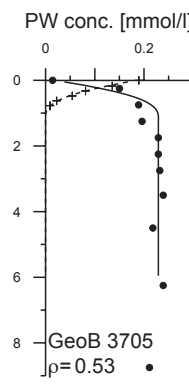

d

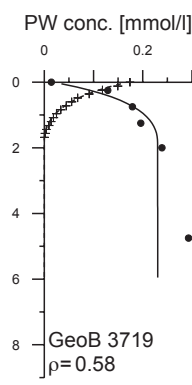

e

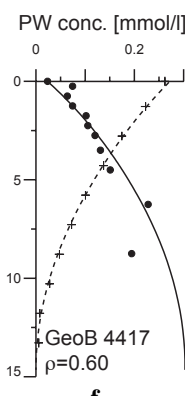

PW conc. [mmol//]

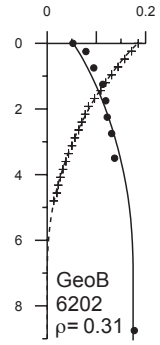

g
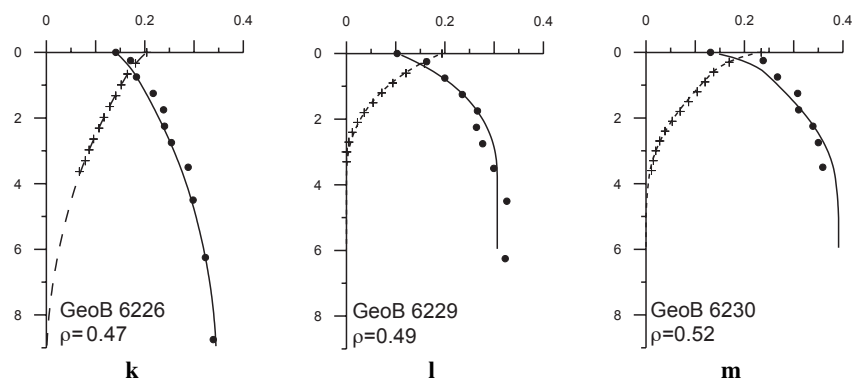

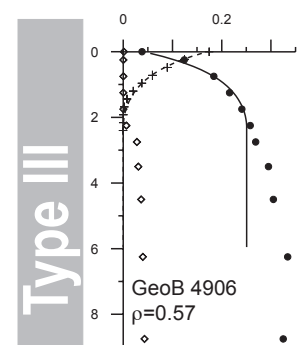

q
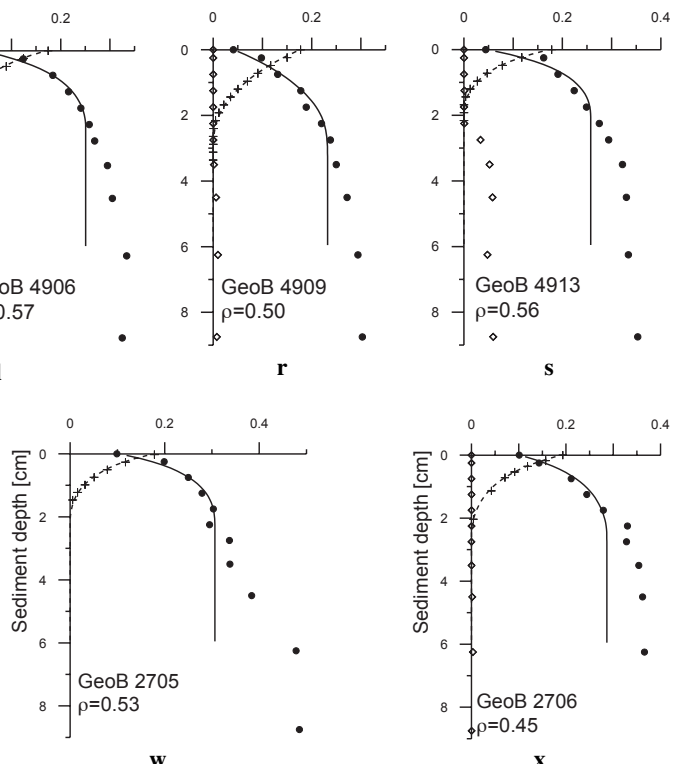

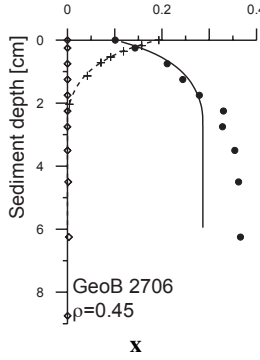

Fig. 4 Comparison of measured and simulated pore water profiles. Crosses and dots indicate the measured $\mathrm{O}_{2}$ and $\mathrm{Si}_{\mathrm{c}}$ concentrations, respectively; diamonds indicate dissolved $\mathrm{Mn}$ in type III GeoB 49 .. pore water profiles; the dashed and continuous lines are model results for $\mathrm{O}_{2}$ and $\mathrm{Si}$, respectively. The lines end where the model column ends. Below, concentrations remain constant. Note that $\mathbf{f}(\mathrm{GeoB} 4417)$ has a different vertical scale. The order of the diagrams is by type of pore water profile: type I, a-n; type II, $\mathbf{o}, \mathbf{p}$; type III, $\mathbf{q}-\mathbf{x}$. $\rho$ is the coupling coefficient used to calculate BSi dissolution rates from aerobic respiration rates according to Eq. (1)

two orders of magnitude (5 to 627 year $^{-1}$ by exponential fitting; Table 2). The Cape Basin shows the highest values; variable values are found throughout the Guinea, Angola, and Argentine basins. The linear relation of kinetic rate constants is statistically significant ( $\mathrm{r}=0.83)$. Assuming proportionality (linearity through origin), the $k:{ }^{k}$ ratios of the subset of type I and II kinetic rate constants are very close to the ratio of diffusivities $D: \check{D}^{\circ}$, as required by our hypothesis expressed in Eq. (14). The subset of type III kinetic rate constants shows lower $k: k$ ratios. This may be explained by partial $\mathrm{O}_{2}$ consumption due to oxidation of reduced species, as indicated by manganese pore water profiles of GeoB 49 . stations (cf. Figs. 4q-t, x), and by decreased BSi solubility. In contrast to the exponential fitting of pore water profiles, kinetic coupling is intrinsic to the pore water model, so that matching kinetic rate constants are expected (Fig. 5b). Deviations from the diffusivity ratio reflect that type III profile simulations, more than others, fail to reach asymptotic $\mathrm{Si}$ 


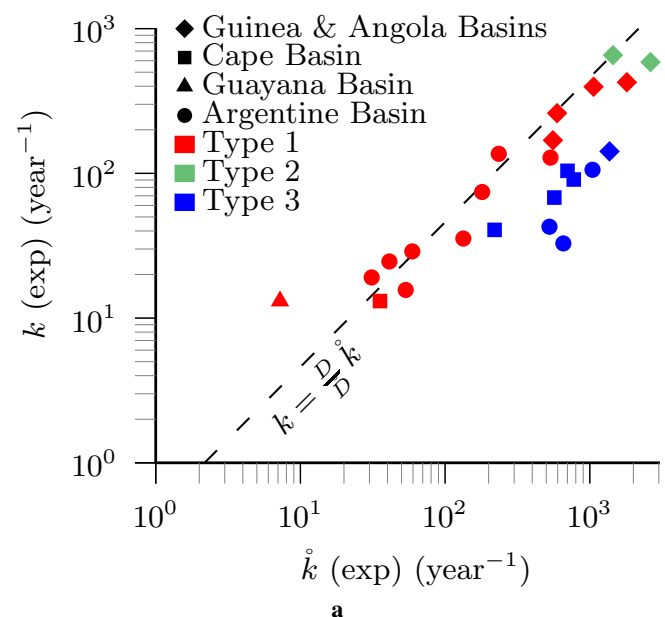

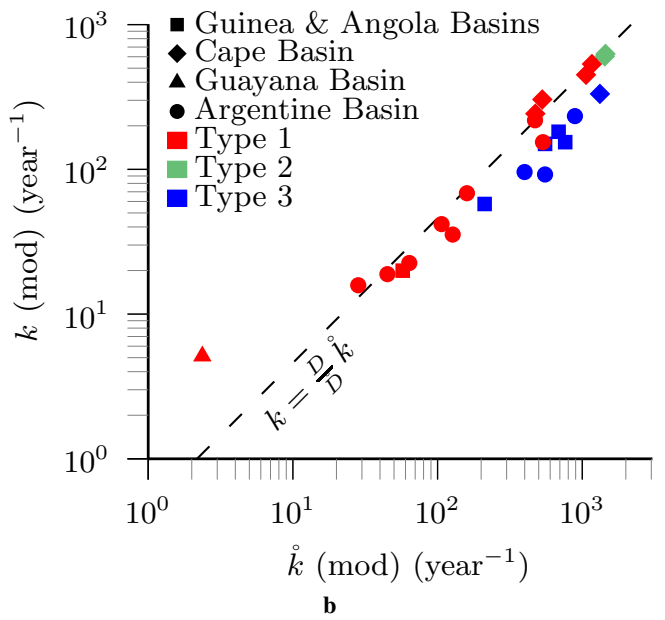

Fig. 5 The kinetic rate constants $k$ and $\stackrel{\circ}{k}$ of aerobic respiration and BSi dissolution a from exponential fitting of pore water profiles are linearly correlated $(\mathrm{r}=0.83)$. According to theory, the proposed relation $k=D / \stackrel{\circ}{k}$ (broken line) is the upper limit of proportionality of kinetic rate constants where $\mathrm{O}_{2}$ is completely used for aerobic respiration. Kinetics of type I and II profiles are very close to this relation. Partial $\mathrm{O}_{2}$ utilization for reoxidation reactions (up to 70\%) could explain deviations to lower proportionality constants as observed for type III profiles. b Corresponding values from pore water modeling with intrinsic coupling of BSi dissolution and aerobic respiration rates according to Eq. (1). Deviations from the proposed relation (broken line) reflect that simulations fail reproducing asymptotic Si concentrations
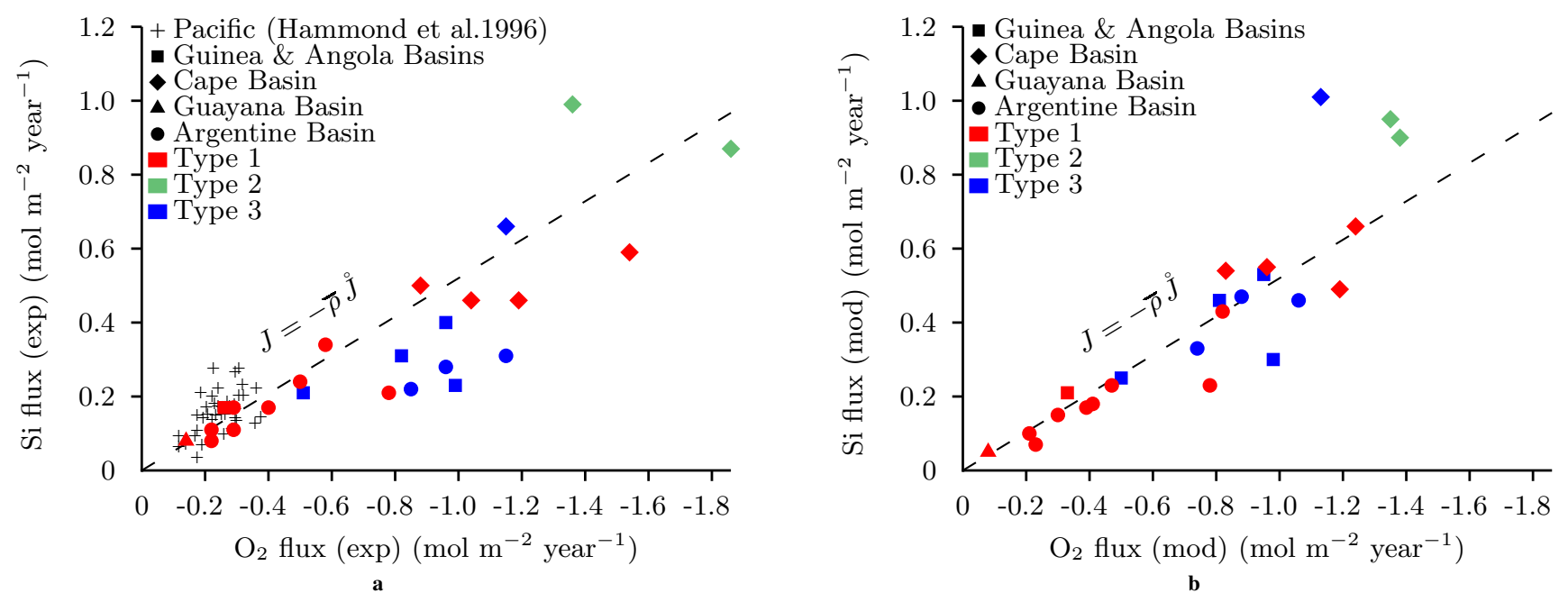

Fig. 6 Benthic Si fluxes from a exponential fit, and $\mathbf{b}$ model fit, plotted against the benthic $\mathrm{O}_{2}$ fluxes of the study stations. Reference data from Hammond et al. (1996) for benthic incubation chambers ( 39 stations) where added to b. The straight broken line has a slope of the average coupling coefficient $\bar{\rho}$ (cf. Eq. 16)

concentrations, suggesting the relevance of at least one additional process for opal dissolution at type III sites.

The linear relation of benthic fluxes of $\mathrm{O}_{2}$ and $\mathrm{Si}$ from both fitting methods is significant (mod: $r=0.89$; exp: $r=0.85$ ). However, the systematic distribution of pore water profile types is not visible in Fig. 6. The data scatter around a straight line with a slope of the average empirical coupling coefficient $\bar{\rho}=0.52$ (single standard deviation). Since scattering of type II and III fluxes is greater than that of type I, and scattering is largely systematic, linear regression was omitted. Data from 39 PACFLUX II and JGOFS benthic incubation chambers from the equatorial Pacific (Hammond et al.,
1996) added to Fig. 6a show comparable $\mathrm{Si}: \mathrm{O}_{2}$ flux ratios for sediments with higher opal contents of 10-20\% (Murray and Leinen, 1993).

Sedimentary $\mathrm{O}_{2}$ uptake (as a proxy for aerobic respiration) is lineary correlated to the solid phase $\mathrm{C}_{\text {org }}(\mathrm{r}=0.67)$, as depicted in Fig. 7 a. There is no linear correlation between benthic Si efflux and opal content in surface sediment depicted in Fig. 7c ( $r=-0.23)$, questioning opal as a suitable proxy for BSi dissolution. A significant linear correlation of benthic Si efflux to surface sediment $\mathrm{C}_{\text {org }}$ content Fig. $7 \mathrm{~b}$ $(\mathrm{r}=0.74)$ underpins the relevance of OM decay for BSi dissolution. Moreover, opal and $\mathrm{C}_{\text {org }}$ content in surface sedi- 

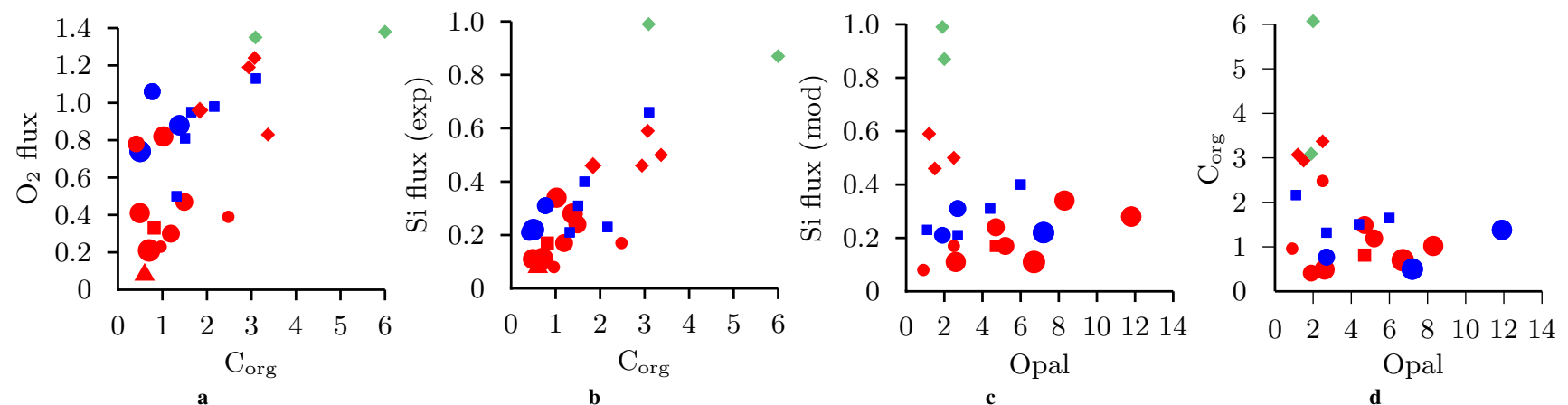

Fig. 7 Plots of a $\mathrm{O}_{2}$ fluxes versus $\mathrm{C}_{\text {org }}$ contents of surface sediments ( $\left.\mathrm{r}=0.67\right)$, b Si fluxes versus $\mathrm{C}_{\text {org }}$ contents of surface sediments ( $\mathrm{r}=0.74$ ), with $\mathrm{Si}$ fluxes from exponential rather than model fit, in order to ensure independence from assumptions concerning OM decay c Si fluxes from model fitting versus opal contents of surface sediments $(\mathrm{r}=-0.23)$ and $\mathbf{d} \mathrm{C}_{\mathrm{org}}$ versus opal contents of surface sediments ( $\mathrm{r}=-0.43$ ). Solids are in $\mathrm{wt} \%$, fluxes in molm ${ }^{-2}$ year $^{-1}$. Colors denote profile type and symbols denote geographic setting (cf. Figs. 5 \& 6 ). Symbol size increases with water depth. Note that opal data exist only for 15 of the 24 stations. Fluxes are diffusive benthic fluxes

Table 2 Comparison of diffusive benthic fluxes of $\mathrm{O}_{2}$ and $\mathrm{Si}$ from model and exponential fitting (in $\mathrm{molm}^{-2}$ year $^{-1}$ ), $\rho$ used in simulations and estimates $\widehat{\rho}$ (assuming $100 \%$ catabolic oxigen utilization), and values for the BSi dissolution kinetic rate constant $k$ (year ${ }^{-1}$ ) from exponential fitting. Profile type is given in parenthesis. Profile type assignment is based on the general shapes of the Si pore water profiles and OPDs

\begin{tabular}{|c|c|c|c|c|c|c|c|c|}
\hline \multirow{2}{*}{\multicolumn{2}{|c|}{ GeoB station (type) }} & \multicolumn{2}{|c|}{$\mathrm{O}_{2}$ flux $(J)$} & \multicolumn{2}{|c|}{ Si flux $(J)$} & \multirow{2}{*}{$\begin{array}{c}\rho \\
\text { calibrated } \\
\end{array}$} & \multirow{2}{*}{$\begin{array}{c}\widehat{\rho} \\
\text { estimated }\end{array}$} & \multirow{2}{*}{$\begin{array}{c}k \\
\text { exp. fit }\end{array}$} \\
\hline & & mod. fit & exp. fit & mod. fit & exp. fit & & & \\
\hline \multicolumn{2}{|c|}{ Guinea and Angola Basin } & & & & & & & \\
\hline 4901 & (I) & -0.33 & -0.26 & 0.21 & 0.17 & 0.63 & 0.73 & 20 \\
\hline 4906 & (III) & -0.81 & -0.82 & 0.46 & 0.31 & 0.57 & 0.74 & 150 \\
\hline 4909 & (III) & -0.50 & -0.51 & 0.25 & 0.21 & 0.50 & 0.65 & 58 \\
\hline 4913 & (III) & -0.95 & -0.96 & 0.53 & 0.40 & 0.56 & 0.73 & 182 \\
\hline \multirow{2}{*}{\multicolumn{2}{|c|}{ Cape Basin }} & -0.98 & -0.99 & 0.30 & 0.23 & 0.31 & 0.46 & 154 \\
\hline & & & & & & & & \\
\hline 3715 & (III) & -1.13 & -1.15 & 1.01 & 0.66 & 0.90 & 1.21 & 333 \\
\hline 3707 & (I) & -0.83 & -0.88 & 0.54 & 0.50 & 0.65 & 0.58 & 304 \\
\hline 3706 & (I) & -1.19 & -1.19 & 0.49 & 0.46 & 0.41 & 0.43 & 449 \\
\hline 3705 & (I) & -1.24 & -1.54 & 0.66 & 0.59 & 0.53 & 0.53 & 533 \\
\hline 3719 & (I) & -0.96 & -1.04 & 0.55 & 0.46 & 0.58 & 0.54 & 243 \\
\hline 3703 & (II) & -1.38 & -1.86 & 0.90 & 0.87 & 0.65 & 0.67 & 627 \\
\hline \multirow{2}{*}{\multicolumn{2}{|c|}{ Guyana Basin }} & -1.35 & -1.36 & 0.95 & 0.99 & 0.71 & 0.73 & 605 \\
\hline & & & & & & & & \\
\hline \multicolumn{2}{|c|}{ Argentine Basin } & -0.08 & -0.14 & 0.05 & 0.08 & 0.60 & 0.29 & 5 \\
\hline 6202 & (I) & -0.23 & -0.22 & 0.07 & 0.08 & 0.31 & 0.32 & 19 \\
\hline 6214 & (I) & -0.39 & -0.40 & 0.17 & 0.17 & 0.45 & 0.56 & 35 \\
\hline 6219 & (I) & -0.30 & -0.29 & 0.15 & 0.17 & 0.50 & 0.57 & 22 \\
\hline 6223 & (I) & -0.41 & -0.29 & 0.18 & 0.11 & 0.44 & 0.48 & 42 \\
\hline 6226 & (I) & -0.21 & -0.22 & 0.10 & 0.11 & 0.47 & 0.43 & 16 \\
\hline 6229 & (I) & -0.47 & -0.50 & 0.23 & 0.24 & 0.49 & 0.51 & 68 \\
\hline 6230 & (I) & -0.82 & -0.58 & 0.43 & 0.34 & 0.52 & 0.52 & 218 \\
\hline 2704 & (III) & -1.06 & -1.15 & 0.46 & 0.31 & 0.43 & 0.57 & 233 \\
\hline 2705 & (III) & -0.88 & -0.96 & 0.47 & 0.28 & 0.53 & 0.89 & 92 \\
\hline 2707 & (I) & -0.78 & -0.78 & 0.23 & 0.21 & 0.30 & 0.37 & 154 \\
\hline 2706 & (III) & -0.74 & -0.85 & 0.33 & 0.22 & 0.45 & 0.62 & 96 \\
\hline
\end{tabular}

ments rather suggest a negative correlation, if any $(\mathrm{r}=-0.46$; Fig. 7d).

In summary, the attributes of the shapes of Si pore water profiles, such as curvature and transition depth to asymptotic concentrations, mirror oxygen profiles in most instances, as shown by simulations. A linear coupling between the kinetics of aerobic respiration and of BSi dissolution follows from the comparison of simple transport and reaction models, and estimates of benthic fluxes of $\mathrm{O}_{2}$ and $\mathrm{Si}$. The simulations do not use BSi solubility as a parameter, and derive $\mathrm{BSi}$ dissolution rates solely from aerobic respiration. Variability in diffusivities, bottom water concentrations, and
BSi solubility are therefore intrinsic to the coupling coefficient $\rho$. The simple transport and reaction models coupled by Eqs. (1) and (4) provide a mechanistic understanding of $\rho$ as a physically based proportionality function $\widehat{\rho}$. Provided that sediments are well oxygenated, benthic Si fluxes can be estimated from aerobic respiration kinetics or $\mathrm{O}_{2}$ flux, bottom water concentrations, and opal solubility according to

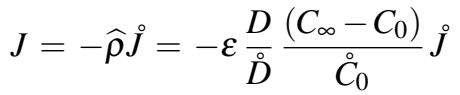

where $\varepsilon$ is the fraction of $\mathrm{O}_{2}$ that is used by aerobic respiration, and not for oxidation of other reduced chemical species. Using the mean coupling coefficient $\bar{\rho}$ as an esti- 
mate for an average value of $\widehat{\rho}$, benthic Si efflux can be assessed from the benthic oxygen uptake (with single standard deviation) as

$J=-0.52 \pm 0.14 \stackrel{\circ}{J}$

Assuming $100 \%$ catabolic oxygen utilization $(\varepsilon=1), \widehat{\rho}$ is a relatively accurate estimator for $\rho$, as shown by a comparison of calculated to model calibrated parameters in Table 2. According to $\rho: \widehat{\rho}$ ratios, oxygen utilization is close to $100 \%$ catabolic at type I and II stations. By contrast, the average share of catabolic oxygen utilization is $72 \pm 11 \%$ (single standard deviation) at type III stations. Calculated from deviations of $k: \stackrel{\circ}{k}$ ratios from the $D: \stackrel{D}{D}$ ratio, values for catabolic oxygen utilization are close to $100 \%$ at type I and II stations, and as low as $50 \%$ on average at type III stations, with a lowest value of $30 \%$.

\section{Discussion}

The simulations produced very good to reasonable fits to the measured Si pore water profiles. On average, the method to reproduce $\mathrm{Si}$ pore water profiles from $\mathrm{O}_{2}$ profiles according to Eq. (1) yielded even better results in terms of squared error analysis than obtained by classical exponential fitting of Si pore water field data. Of cause, the uncertainty of the resulting fluxes from both methods may be considerable, because within the upper 1-2 cm of sediment, where the major increase in pore water concentration occurs in most cases, only very few Si data points exist. Moreover, they are systematically biased as pointed out above. In most cases, the oxygen penetration depth coincides with the transition from increasing to asymptotic behavior of the Si profiles, which is yet another indicator for the importance of microbenthic activity for BSi dissolution. However, both type II Si profiles tend to dip below oxygen penetration depth which can be ascribed to the formation of Si minerals (Michalopoulos et al., 2000; Michalopoulos and Aller, 2004), or may indicate non-stationary conditions due to seasonal variations in phytodetritus deposition (Gallinari et al., 2008).

Nevertheless, a significant positive linear correlation of benthic $\mathrm{Si}$ release and $\mathrm{O}_{2}$ uptake exists in the dataset presented (Fig. 6). The positive correlation of benthic BSi dissolution and aerobic respiration is even more pronounced if the kinetics of the respective reactions is examined by correcting benthic fluxes for boundary conditions (bottom water concentrations) and material-specific parameters (BSi solubility, diffusivities). Figure 5 a suggests that, at each depth increment of the sediment, the BSi dissolution rate is related to the aerobic respiration rate by proportionality of the related kinetic rate constants. As these include all relevant parameters which affect the reaction rate-apart from concentration-such as temperature, ionic strength, surface area, and enzymatic activity, the existence of a common cause for both aerobic respiration and BSi dissolution is most likely. A number of possible explanations for the observed correlations were evaluated as follows: There is obviously no close coupling of BSi and OM in the particle flux to the seafloor and within the sediment which could explain the correlation of $\mathrm{Si}: \mathrm{O}_{2}$ fluxes. Although both $\mathrm{BSi}$ and $\mathrm{OM}$ are major components of diatoms that are found in certain ratios in the living organisms (Ragueneau et al., 2000, 2002), the biogeochemical cycles of silicon and carbon decouple both vertically and horizontally in the water column (Rivkin et al., 1996; Gallinari et al., 2002; Ragueneau et al., 2002). Considering the multitude of water depths, and the different regions investigated, related concentrations in the particle rain reaching the seafloor are highly unlikely. This is substantiated by the field data of $\mathrm{C}_{\text {org }}$ and opal, which clearly do not show any positive linear $\mathrm{Si}$ : C correlation in the surface sediment (Fig. 7d). The data show a negative relation, with opal being enriched with increasing water depth, reflecting fast organic matter degradation and slow BSi dissolution during water column transit.

It has been hypothesized by Lee et al. (2000) and Hedges et al. (2001) that mineral ballast $\left(\mathrm{BSi}, \mathrm{CaCO}_{3}\right.$, and terrigenous compounds) inhibit carbon mineralization before reaching the sediment surface. Then, the correlation of benthic Si release and $\mathrm{O}_{2}$ uptake in the dataset could be a result of $\mathrm{BSi}$ protecting the cytoplasmic OM from decay, as proposed by Armstrong et al. (2002) and Moriceau et al. (2009) for sinking particles in the water column. Applied to the sediment, this would explain correlating BSi dissolution and OM mineralization without the need of bacterial mediation of BSi dissolution. This concept is exactly opposite to our hypothesis, but does not explain that the oxygen penetration depth coincides with the transition depth from fast BSi dissolution to asymptotic Si concentrations, and it seems rather unlikely that BSi reactivity drops where oxygen is depleted.

\section{Sensitivity of Si fluxes to kinetic rate constants and BSi sol-} ubility

According to the simple models presented, the kinetic rate constant and the solubility are major control parameters of BSi dissolution. Their impact on BSi dissolution, and their natural variability determine their significance for Si flux estimates. It can be deduced from Eq. (15) that the efflux of $\mathrm{Si}$ is proportional to the saturation deficit, and proportional to the square root of the kinetic rate constant. For the data used in this study, solubility varies between 177 and $479 \mu \mathrm{moll}^{-1}$, and elsewhere has been observed to range from 200 to 1,500 $\mathrm{mmol}^{-1}$ (e.g., Van Cappellen and Qiu, 1997a; Van Cappellen et al., 2002; Dixit and Van Cappellen, 2003), spanning about one order of magnitude. However, within a given region, the variability is usually much less. In contrast, the kinetic rate constant varies between 5 and 
627 , its square root spanning over one order of magnitude. Accordingly, statistical analysis reveals that the major proportion of the Si flux variability is accounted for by the variability of the kinetic rate constant of aerobic respiration.

\section{Type III pore water profiles}

Type III profiles show Si concentrations increasing below the OPD, and seem to follow a more complex kinetics than if being simply coupled to oxygen uptake. At least for GeoB 4906, 4917, and 4913, considerable consumption of $\mathrm{O}_{2}$ for the oxidation of reduced $\mathrm{Mn}$ is indicated by $\mathrm{Mn}^{+2}$ pore water profiles (Fig. $4 \mathrm{q}-\mathrm{t}$ ). Indeed, existing pore water data for type I and type II locations suggest no pronounced oxidation of Mn (M. Zabel, personal communication), which supports the interpretation of a mainly catabolic oxygen utilization at these sites. Since data for the remaining major reduced species are scarce $\left(\mathrm{H}_{2} \mathrm{~S}, \mathrm{Fe}, \mathrm{CH}_{4}\right)$, a reliable assessment of catabolic oxygen utilization ratio at the investigated stations was omitted. The deviating kinetics at type III locations suggest that 30 to $50 \%$ of the $\mathrm{O}_{2}$ are used up for the oxidation of reduced species, which are not uncommon values (Canfield et al., 1993; Thamdrup and Canfield, 1996). The low water depths and shallow OPDs of the type III profiles in the Guinea and Angola basins substantiate the possibility that these locations may be supplied with more labile OM, and support considerable anaerobic mineralization providing significant amounts of reduced chemical species. Moreover, the type III locations all lie in areas of enhanced terrigenous input; hence, reduced $\mathrm{BSi}$ solubility (due to incorporated traces of $\mathrm{Al}$ ) which would also cause deviating kinetics (Dixit et al., 2001; Romero and Hensen, 2002; Gehlen et al., 2002). For the data presented, BSi solubility increases with water depth in the Argentine Basin, which may reflect decreasing terrigenous impact further offshore. In the other regions, water depth and solubility are not correlated. Since the variability of solubility within a given region is generally greater than differences between regional averages, a significant terrigenous impact on BSi solubility cannot be deduced from the data.

If only aerobic bacteria were to mediate the dissolution of $\mathrm{BSi}$, then the type III Si pore water profiles could not be explained in terms of microbial mediation. Subsequently, $\mathrm{Si}$ concentrations keep on increasing beneath the OPD at these stations, indicating ongoing $\mathrm{BSi}$ dissolution in the anoxic zone. In conclusion, if microbial OM degradation leads to enhanced BSi dissolution, anaerobic heterotrophs also may enhance BSi dissolution, causing increasing Si concentrations below the OPD at type III sites. The mediation of BSi dissolution by anaerobic bacteria below the OPD is supported by the fact that the simulated $\mathrm{Si}$ pore water profiles fit the field data particularly well at locations with deeper $\mathrm{O}_{2}$ penetration $(>4 \mathrm{~cm})$, and lower surficial $\mathrm{C}_{\text {org }}$ content. Apparently, anaerobic activity is very limited at these sites, and the major microbial activity is located within the oxic zone and is represented by $\mathrm{O}_{2}$ uptake.

The trend in the BSi dissolution kinetics data shown in Fig. 5 suggests decoupling from respiration kinetics at low respiration rates, though this is barely distinguishable from scattering. If real, this would be consistent with the interpretation that opal dissolution occurs also as a purely physical process, without the help of bacteria. At very low respiration rates, as well as in highly siliceous sediments, this nonbiologically mediated BSi dissolution might reach with or even exceed the bacteria-mediated BSi dissolution, so that coupled kinetics of respiration and BSi dissolution might be limited to certain sediment compositions.

\section{Kinetics and reactive surface area}

It is a common and well-founded assumption that the reaction rate of dissolving $\mathrm{BSi}$ relates to its reactive surface area. The question remains as to why the kinetic rate constant and the benthic Si flux are apparently insensitive to the surficial sediment opal content (Fig. 7c), which is usually assumed to be a good representative of surface area availability. Analogously to OM, for which variable degradability weakens the impact of the solid phase concentration on aerobic respiration rates and benthic $\mathrm{O}_{2}$ uptake (Fig. 7a), BSi may also consist of several fractions of variable reactivity, as proposed by Schink et al. (1975). This would obscure the impact of surface area as such on BSi dissolution. A heterogeneous oceanographic setting may display considerable variations in BSi reactivity through variations in undersaturation, temperature, aluminum levels, and specific surface area. According to Van Cappellen et al. (2002), each of these factors may theoretically result in dissolution rate variations of about one order of magnitude. Additionally, spatiotemporal variations of BSi reactivity are supposedly related to biomineralization conditions in surface waters (Van Bennekom et al., 1991; Van Beusekom et al., 1997). Nevertheless, a consistent BSi reactivity pattern should be expected within a given oceanographic setting. On a regional basis, except in the Cape Basin, the Si fluxes reported in the present study seem to correlate with sedimentary opal contents, but a reliable statistical analysis of region-specific trends would require more data.

Possibly, the surface sediment opal content rather represents the refractory fraction that is decoupled from particular BSi downflux and Si efflux. Since most of the BSi reaching the sediment surface is recycled (approx. 95\%), the BSi downflux generally correlates well with $\mathrm{Si}$ efflux for a wide range of oceanographic settings. By contrast, the burial flux can be related to $\mathrm{BSi}$ downflux only in cases of a high $\mathrm{BSi}$ rain rate. 
These sediments commonly have high sedimentary opal contents and low recycling efficiencies (Ragueneau et al., 2000). The sites investigated in this study, and sites where other researchers found corresponding $\mathrm{Si}$ and $\mathrm{O}_{2}, \mathrm{CO}_{2}$, or $\mathrm{NO}_{3}$ fluxes or pore water profiles (Martin et al., 1991; Devol and Christensen, 1993; Hall et al., 1996; Berelson et al., 2005) rather display high recycling efficiencies and have low opal contents. This may potentially cause high errors when using the Si burial flux as a measure of the benthic Si efflux and demonstrates the apparent insensitivity of the benthic $\mathrm{Si}$ flux to the surficial opal content. The coupling of BSi dissolution to (aerobic) respiration may be limited to sites of low BSi rain rates with accordingly high recycling efficiencies and low opal content of the sediment. Variability in the regional dominance of microbially mediated BSi dissolution may even be of fundamental importance for the bimodal global opal accumulation pattern.

Our simple BSi and OM degradation models do not explicitly relate to surface area. Any potential effect of surface area is therefore incorporated in the kinetic rate constants. The good correlation of the kinetic rate constants $k$ and $k$ indicates that the kinetics of $\mathrm{BSi}$ dissolution is related to the kinetics of OM degradation, rather than to an intrinsic property of the solid BSi phase, as the latter would require a close coupling of BSi and OM in the particle downflux, which is not the case. Further investigations that integrate studies on how BSi and OM are associated within particles (Schrader, 1971; Tande and Slagstad, 1985; Ragueneau et al., 2002), the structure of diatom skeletons (Hecky et al., 1973; Wetherbee et al., 2000; Volcani, 2002), and models on the use and spreading of hydrolytic enzymes by bacteria (Vetter et al., 1998; Rothman and Forney, 2007) are necessary to elucidate the conditions under which bacteria may mediate BSi dissolution, and the low impact of sediment opal contents on its dissolution rate.

\section{How bacteria may contribute to BSi dissolution}

The identification of the detailed mechanism that leads to the conformity of the kinetics of opal dissolution and aerobic, and possibly also anaerobic, respiration is, however beyond the scope of this study and must be addressed by micobiological investigations in the future. It can be hypothesized that hydrolytic enzymes are an important factor for BSi dissolution. Bidle and Azam (1999, 2001) showed a significant acceleration of BSi dissolution by bacterial hydrolytic exoenzymes in batch experiments. Heterotrophic bacteria use exoenzymes for the extracellular degradation of highly polymeric substrates into macronutrients that can be assimilated. The exoenzymes may also attack organic components (not coatings) of the diatom frustule that have been integrated into the BSi matrix during valve morphogenesis (Hecky et al., 1973; Kröger et al., 2002; Volcani, 2002) and may act as corrosion inhibitors (Picket-Heaps et al., 1990; Wetherbee et al., 2000). Upon destruction of the protecting organic substances, the BSi dissolution rate should be notably enhanced. Extending results from activated sludge and wastewater, the hydrolysis rates under aerobic and anoxic conditions relate to the respiration rates (Henze and Mladenovski, 1991; Goel et al., 1998), which would account for the relative importance of aerobic respiration for BSi dissolution. Indeed, in laboratory studies the recycling efficiency of opal has been shown to correlate with bacterial metabolic activity (Bidle et al., 2002).

\section{Conclusions}

In the present study, the analysis of $\mathrm{O}_{2}$ and $\mathrm{Si}$ pore water profiles from continental margin sediments of the Southern Atlantic indicates that the aerobic respiration kinetic rate constant is the main control parameter of the variability of benthic Si fluxes in oxygenated sediments. This concept of microbial mediation of BSi dissolution may help to resolve the difficulties that usually arise when interpreting the kinetic rate constants as an intrinsic property of the BSi phase, and explain its high variability on a regional and even local scale. This phenomenon may also be partly responsible for deviations of in situ and in vitro results-especially if not accounted for by experiment design. Through its simplicity, relative accuracy, and broad geographic applicability, the proposed BSi dissolution model appears to be suitable for diagenetic and coupled benthic-pelagic models. Depending on the complexity of the approach, Eq. (15) or the parameterized form Eq. (16) can be used. Applicable for regional Si budget assessments of the oligo- and mesotrophic regions of the world ocean, the $\mathrm{Si}-\mathrm{O}_{2}$ coupling reported here complements a set of empirical relations provided by, e.g., Jahnke (1996) or Pfeifer et al. (2002) which, in combination, can be used for the prediction of total diagenetic dissolution of biogenic particles, i.e., the non-lithogenic particle flux that basically consists of organic material, $\mathrm{CaCO}_{3}$, and $\mathrm{BSi}$. Currently limited to sediments that are well-oxygenated and preserve opal, our findings may possibly be extrapolated to oxygen depleted oceanic environments.

Acknowledgements Constructive comments and suggestions by Bernard P. Boudreau, Gunnar Brandt, and two anonymous reviewers are greatly acknowledged. We thank Kerstin Pfeifer, Katherina Seiter, and Matthias Zabel for fruitful discussions on the subject. Special thanks go to Frank Wenzhöfer and Matthias Zabel for supplying in situ $\mathrm{O}_{2}$ and Mn data. This work was supported by the DFG projects FOR 432 and SFB 754. 


\section{References}

Adler M, Hensen C, Schulz HD (2000) CoTReM - Column Transport and Reaction Model. Version 2.3, User Guide. Faculty of Geochemistry, University of Bremen

Adler M, Hensen C, Wenzhöfer F, Pfeifer K, Schulz HD (2001) Modeling of calcite dissolution by oxic respiration in supralysoclinal deep-sea sediments. Mar Geol 177:167-189

Archer D, Lyle M, Rodgers K, Froelich P (1993) What controls opal preservation in tropical deep-sea sediments? $\mathrm{Pa}$ leoceanography 8:7-21

Armstrong RA, Lee C, Hedges JI, Honjo S, Wakeham SG (2002) A new, mechanistic model for organic carbon fluxes in the ocean based on the quantitative association of POC with ballast minerals. Deep-Sea Res II 49:219236

Barker P, Fontes JC, Gasse F, Druart JC (1994) Experimental dissolution of diatom silica in concentrated salt solutions and implications for paleoenvironmental reconstruction. Limnol Oceanogr 39(1):99-110

Berelson WM, Hammond DE, Johnson KS (1987) Benthic fluxes and the cycling of biogenic silica and carbon in two southern-California borderland basins. Geochim Cosmochim Acta 51:1345-1363

Berelson WM, Prokopenko M, Sansone FJ, Graham AW, McManus J, Bernhard JM (2005) Anaerobic diagenesis of silica and carbon in continental margin sediments: Discrete zones of $\mathrm{TCO}_{2}$ production. Geochim Cosmochim Acta 69:4611-4629

Berner RA (1980) Early diagenesis: a theoretical approach. Princton University Press, Princton, NJ

Bidle KD, Azam F (1999) Accelerated dissolution of diatom silica by marine bacterial assemblages. Nature 397:508512

Bidle KD, Azam F (2001) Bacterial control of silicon regeneration from diatom detritus: significance of bacterial ectohydrolases and species identity. Limnol Oceanogr 46:1606-1623

Bidle KD, Manganelli M, Azam F (2002) Regulation of oceanic silicon and carbon preservation by temperature control on bacteria. Science 298:1980-1984

Boudreau BP (1990a) Asymptotic forms and solutions of the model for silica-opal diagenesis in bioturbated sediments. J Geophys Res Oceans 95:7367-7379

Boudreau BP (1990b) Modeling early diagenesis of silica in non-mixed sediments. Deep-Sea Res A 37:1543-1567

Boudreau BP (1997) Diagenetic models and their implementation. Modelling transport and reactions in aquatic sediments. Springer, Berlin Heidelberg New York

Canfield DE, Jorgensen BB, Fossing H, Glud R, Gundersen J, Ramsing NB, Thamdrup B, Hansen JW, Nielsen LP, Hall POJ (1993) Pathways of organic-carbon oxidation in
3 continental-margin sediments. Mar Geol 113:27-40

DeMaster DJ (1981) The supply and accumulation of silica in the marine-environment. Geochim Cosmochim Acta 45:1715-1732

DeMaster DJ (2002) The accumulation and cycling of biogenic silica in the southern ocean: revisiting the marine silica budget. Deep-Sea Res II 49:3155-3167

Devol AH, Christensen JP (1993) Benthic fluxes and nitrogen cycling in sediments of the continental margin of the eastern North Pacific. J Mar Res 51:345-372

Dixit S, Van Cappellen P (2002) Surface chemistry and reactivity of biogenic silica. Geochim Cosmochim Acta 66:2559-2568

Dixit S, Van Cappellen P (2003) Predicting benthic fluxes of silicic acid from deep-sea sediments. J Geophys Res Oceans 108(C10), 3334. doi:10.1029/2002JC001309

Dixit S, Van Cappellen P, Van Bennekom AJ (2001) Processes controlling solubility of biogenic silica and pore water build-up of silicic acid in marine sediments. Mar Chem 73:333-352

Dugdale RC, Wilkerson FP (1998) Silicate regulation of new production in the equatorial Pacific upwelling. Nature 391:270-273

Dugdale RC, Wilkerson FP, Minas HJ (1995) The role of a silicate pump in driving new production. Deep-Sea Res I 42:697-719

Egge JK, Aksnes DL (1992) Silicate as regulating nutrient in phytoplankton competition. Mar Ecol 83:281-289

Froelich PN, Klinkhammer GP, Bender ML, Luedtke NA, Heath GR, Cullen D, Dauphin P, Hammond D, Hartman B, Maynard V (1979) Early oxidation of organic matter in pelagic sediments of the eastern equatorial Atlantic suboxic diagenesis. Geochim Cosmochim Acta 43:10751090

Gallinari M, Ragueneau O, Corrin L, DeMaster DJ, Tréguer P (2002) The importance of water column processes on the dissolution properties of biogenic silica in deepsea sediments i. solubility. Geochim Cosmochim Acta 66:2701-2717

Gallinari M, Ragueneau O, DeMaster D, Hartnett H, Rickert D, Thomas C (2008) Influence of seasonal phytodetritus deposition on biogenic silica dissolution in marine sediments-Potential effects on preservation. DeepSea Res II 55(22/23):2451-2464

Gehlen M, Beck L, Calas G, Flank AM, Van Bennekom AJ, Van Beusekom JEE (2002) Unraveling the atomic structure of biogenic silica: Evidence of the structural association of $\mathrm{Al}$ and $\mathrm{Si}$ in diatom frustules. Geochim Cosmochim Acta 66:1601-1609

Glud RN, Gundersen JK, Jørgensen BB, Revsbech NP, Schulz HD (1994) Diffusive and total uptake of deep-sea sediments in the eastern South Atlantic Ocean: In situ and laboratory measurements. Deep-Sea Res I 41:1767-1788 
Goel R, Mino T, Satoh H, Matsuo T (1998) Comparison of hydrolytic enzyme systems in pure culture and activated sludge under different electron acceptor conditions. Water Sci Technol 37(4/5):335-343

Greenwood JE, Truesdale VW, Rendell AR (2001) Biogenic silica dissolution in seawater - in vitro chemical kinetics. Progr Oceanogr 48:1-23

Hall POJ, Hulth S, Hulthe G, Landen A, Tengberg A (1996) Benthic nutrient fluxes on a basin-wide scale in the Skagerrak (north-eastern North Sea). J Sea Res 35:123-137

Hammond DE, McManus J, Berelson WM, Kilgore TE, Pope RH (1996) Early diagenesis of organic material in equatorial Pacific sediments: stoichiometry and kinetics. Deep-Sea Res II 43:1365-1412

Hecky RE, Mopper K, Kilham P, Degens ET (1973) The amino acid and sugar composition of diatom cell-walls. Mar Biol 19:323-331

Hedges JI, Baldock JA, Gelinas Y, Lee C, Peterson M, Wakeham SG (2001) Evidence for non-selective preservation of organic matter in sinking marine particles. Nature 409:801-804

Hensen C, Landenberger H, Zabel M, Schulz HD (1998) Quantification of diffusive benthic fluxes of nitrate, phosphate, and silicate in the southern Atlantic Ocean. Global Biogeochem Cycles 12:193-210

Hensen C, Zabel M, Schulz HD (2000) A comparison of benthic nutrient fluxes from deep-sea sediments off Namibia and Argentina. Deep-Sea Res II 47:2029-2050

Hensen C, Zabel M, Pfeifer K, Schwenk T, Kasten S, Riedinger N, Schulz HD, Boettius A (2003) Control of sulfate pore-water profiles by sedimentary events and the significance of anaerobic oxidation of methane for the burial of sulfur in marine sediments. Geochim Cosmochim Acta 67:2631-2647

Henze M, Mladenovski C (1991) Hydrolysis of particulate substrate by activated sludge under aerobic, anoxic and anaerobic conditions. Water Res 25(1):61-64

Jahnke RA (1996) The global ocean flux of particulate organic carbon: areal distribution and magnitude. Global Biogeochem Cycles 10:71-88

Jin X, Gruber N, Dunne JP, Sarmiento JL, Armstrong RA (2006) Diagnosing the contribution of phytoplankton functional groups to the production and export of particulate organic carbon, $\mathrm{CaCO}_{3}$, and opal from global nutrient and alkalinity distributions. Global Biogeochem Cycles 20. doi:10.1029/2005GB002532

Kamatani A, Ejiri N, Tréguer P (1988) The dissolution kinetics of diatom ooze from the Antarctic area. Deep-Sea Res A 35:1195-1203

Keir RS (1982) Dissolution of calcite in the deep-sea - theoretical prediction for the case of uniform size particles settling into a well-mixed sediment. Am J Sci 282:193236
Khalil K, Rabouille C, Gallinari M, Soetaert K, DeMaster D, Ragueneau O (2007) Constraining biogenic silica dissolution in marine sediments: a comparison between diagenetic models and experimental dissolution rates. Mar Chem 106(1/2):223 - 238

Kröger N, Lorenz S, Brunner E, Sumper M (2002) Selfassembly of highly phosphorylated silaffins and their function in biosilica morphogenesis. Science 298:584586

Landenberger H, Adler M, Zabel M, Hensen C, Schulz HD (1997) Softwareentwicklung zur computerunterstützten Simulation frühdiagenetischer Prozesse in marinen Sedimenten. Z deutsch geol Gesellsch 148:447-455

Lee C, Wakeham SG, Hedges JI (2000) Composition and flux of particulate amino acids and chloropigments in equatorial Pacific seawater and sediments. Deep-Sea Res I 47:1535-1568

Lewin JC (1961) The dissolution of silica from diatom walls. Geochim Cosmochim Acta 21:182-198

Luce RW, Bartlett RW, Parks GA (1972) Dissolution kinetics of magnesium silicates. Geochim Cosmochim Acta 36:35-50

Mann DG (1999) The species concept in diatoms. Phycologia 38:437-495

Martin WR, Bender M, Leinen M, Orchardo J (1991) Benthic organic-carbon degradation and biogenic silica dissolution in the central equatorial Pacific. Deep-Sea Res A 38:1481-1516

McManus J, Hammond DE, Berelson WM, Kilgore TE, DeMaster DJ, Ragueneau OG, Collier RW (1995) Early diagenesis of biogenic opal - dissolution rates, kinetics, and paleoceanographic implications. Deep-Sea Res II 42:871-903

Michalopoulos P, Aller RC (2004) Early diagenesis of biogenic silica in the Amazon delta: alteration, authigenic clay formation, and storage. Geochim Cosmochim Acta 68:1061-1085

Michalopoulos P, Aller RC, Reeder RJ (2000) Conversion of diatoms to clays during early diagenesis in tropical, continental shelf muds. Geology 28:1095-1098

Moriceau B, Goutx M, Guigue C, Lee C, Armstrong R, Duflos M, Tamburini C, Charrière B, Ragueneau O (2009) $\mathrm{Si}-\mathrm{C}$ interactions during degradation of the diatom Skeletonema marinoi. Deep-Sea Res II 56(18):1381 - 1395

Müller PJ, Schneider R (1993) An automated leaching method for the determination of opal in sediments and particulate matter. Deep-Sea Res I 40:425-444

Murray RW, Leinen M (1993) Chemical transport to the seafloor of the equatorial Pacific Ocean across a latitudinal transect at $135^{\circ} \mathrm{W}$ : tracking sedimentary major, trace, and rare earth element fluxes at the Equator and the Intertropical Convergence Zone. Geochim Cosmochim Acta 57(17):4141 - 4163 
Nelson DM, Tréguer P, Brzezinski MA, Leynaert A, Queguiner B (1995) Production and dissolution of biogenic silica in the ocean - revised global estimates, comparison with regional data and relationship to biogenic sedimentation. Global Biogeochem Cycles 9:359-372

Pfeifer K, Hensen C, Adler M, Wenzhöfer F, Weber B, Schulz HD (2002) Modeling of subsurface calcite dissolution, including the respiration and reoxidation processes of marine sediments in the region of equatorial upwelling off Gabon. Geochim Cosmochim Acta 66:4247-4259

Picket-Heaps J, Tippit DH, Andreozzi JA (1990) The cell biology of diatom valve formation. In: Round FE, Chapman DJ (eds) Progress in Phycological Research, vol 7. Biopress, Bristol, pp 1-168

Rabouille C, Gaillard JF, Tréguer P, Vincendeau MA (1997) Biogenic silica recycling in surficial sediments across the Polar Front of the Southern Ocean (Indian Sector). DeepSea Res I 44:1151-1176

Ragueneau O, Tréguer P, Leynaert A, Anderson RF, Brzezinski MA, DeMaster DJ, Dugdale RC, Dymond J, Fischer G, Francois R, Heinze C, Maier-Reimer E, Martin-Jezequel V, Nelson DM, Queguiner B (2000) A review of the $\mathrm{Si}$ cycle in the modern ocean: recent progress and missing gaps in the application of biogenic opal as a paleoproductivity proxy. Global Planet Change 26:317-365

Ragueneau O, Dittert N, Pondaven P, Tréguer P, Corrin L (2002) Si/C decoupling in the world ocean: Is the Southern Ocean different? Deep-Sea Res II 49:3127-3154

Rickert D, Schlüter M, Wallmann K (2002) Dissolution kinetics of biogenic silica from the watercolumn to the sediments. Geochim Cosmochim Acta 66:439-455

Rivkin RB, Legendre L, Deibel D, Tremblay JE, Klein B, Crocker K, Roy S, Silverberg N, Lovejoy C, Mesple F, Romero N, Anderson MR, Matthews P, Savenkoff C, Vezina $\mathrm{A}$, Therriault JC, Wesson $\mathrm{J}$, Berube $\mathrm{C}$, Ingram RG (1996) Vertical flux of biogenic carbon in the ocean: Is there food web control? Science 272:1163-1166

Romero O, Hensen C (2002) Oceanographic control of biogenic opal and diatoms in surface sediments of the Southwestern Atlantic. Mar Geol 186:263-280

Rothman DH, Forney DC (2007) Physical model for the decay and preservation of marine organic carbon. Science 316:1325-1328

Sayles FL, Deuser WG, Goudreau JE, Dickison WH, Jickells TD, King P (1996) The benthic cycle of biogenic opal at the Bermuda Atlantic Time Series site. Deep-Sea Res I 43:383-409

Schink DR, Guinasso NL, Fanning KA (1975) Processes affecting concentration of silica at sediment-water interface of Atlantic Ocean. J Geophys Res Oceans Atmospheres 80:3013-3031
Schrader HJ (1971) Fecal pellets: role in sedimentation of pelagic diatoms. Science 174:55-57

Seiter K, Hensen C, Schroter E, Zabel M (2004) Organic carbon content in surface sediments - defining regional provinces. Deep-Sea Res I 51:2001-2026

Tande K, Slagstad D (1985) Assimilation efficiency in herbivorous aquatic organisms - the potential of the ratio methods using ${ }^{14} \mathrm{C}$ and biogenic silica as markers. Limnol Oceanogr 30:1093-1099

Thamdrup B, Canfield DE (1996) Pathways of carbon oxidation in continental margin sediments off central Chile. Limnol Oceanogr 41:1629-1650

Tréguer P, Nelson DM, Van Bennekom AJ, Demaster DJ, Leynaert A, Queguiner B (1995) The silica balance in the world ocean - a reestimate. Science 268:375-379

Truesdale VW, Greenwood JE, Rendell AR (2005) In vitro, batch-dissolution of biogenic silica in seawater - the application of recent modelling to real data. Progr Oceanogr 66(1): $1-24$

Van Bennekom AJ, Buma AGJ, Nolting RF (1991) Dissolved aluminum in the Weddell-Scotia confluence and effect of $\mathrm{Al}$ on the dissolution kinetics of biogenic silica. Mar Chem 35:423-434

Van Beusekom JEE, Van Bennekom AJ, Tréguer P, Morvan J (1997) Aluminium and silicic acid in water and sediments of the Enderby and Crozet Basins. Deep-Sea Res II 44:987-1003

Van Cappellen P, Qiu LQ (1997a) Biogenic silica dissolution in sediments of the Southern Ocean. 1. Solubility. DeepSea Res II 44:1109-1128

Van Cappellen P, Qiu LQ (1997b) Biogenic silica dissolution in sediments of the Southern Ocean. 2. Kinetics. Deep-Sea Res II 44:1129-1149

Van Cappellen P, Dixit S, Van Beusekom J (2002) Biogenic silica dissolution in the oceans: reconciling experimental and field-based dissolution rates. Global Biogeochem Cycles 16(4), 1075. doi:10.1029/2001GB001431

Vetter YA, Deming JW, Jumars PA, Krieger-Brockett BB (1998) A predictive model of bacterial foraging by means of freely released extracellular enzymes. Microb Ecol 36:75-92

Volcani BE (2002) Cell wall formation in diatoms: morphogenesis and biochemistry. In: Simpson TL, Volcani, BE (eds) Silicon and siliceous structures in biological systems. Springer, Berlin Heidelberg New York, pp 157-200

Wenzhöfer F, Glud RN (2002) Benthic carbon mineralization in the Atlantic: a synthesis based on in situ data from the last decade. Deep-Sea Res I 49:1255-1279

Wenzhöfer F, Adler M, Kohls O, Hensen C, Strotmann B, Schulz HD (2001) Calcite dissolution driven by benthic mineralization in the deep-sea: In situ measurements of $\mathrm{Ca}^{2+}, \mathrm{pH}, \mathrm{pCO}_{2}$ and $\mathrm{O}_{2}$. Geochim Cosmochim Acta 65:2677-2690 
Wetherbee R, Crawford S, Mulvaney P (2000) The nanostructure and development of diatom biosilica. In: Baeurlein E (ed) Biomineralization: From biology to biotechnology and medical application, Wiley-VCH, Weinheim, pp 189-206

Zabel M, Dahmke A, Schulz HD (1998) Regional distribution of diffusive phosphate and silicate fluxes through the sediment water interface - The eastern South Atlantic.

Deep-Sea Res I 45:277-300 